\title{
Performance of Three Rambutan Varieties (Nephelium lappaceum L.) on Various Nursery Media
}

Khalilal Mitras, James M. Roshetko, Sabaruddin and Nurhayati 



\section{Performance of Three Rambutan Varieties(Nephelium lappaceum L.) on Various Nursery Media}

Khalilal Mitras, James M. Roshetko, Sabaruddin and Nurhayati

Working Paper no. 136 


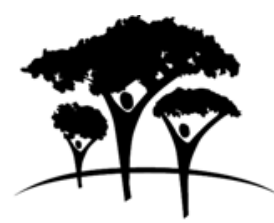

World Agroforestry Centre

TRANSFORMING LIVES AND LANDSCAPES

\section{citation:}

Mitras K, Roshetko JM, Sabaruddin, and Nurhayati. 2011. Performance of Three Rambutan Varieties (Nephelium lappaceum L.) on Various Nursery Media. ICRAF Working Paper Series. nr 136. Bogor, Indonesia. World Agroforestry Centre, 10 p. http://dx.doi.org/10.5716/WP11232.PDF

Titles in the Working Paper Series aim to disseminate interim results on agroforestry research and practices and stimulate feedback from the scientific community. Other publication series from the World Agroforestry Centre include: Agroforestry Perspectives, Technical Manuals and Occasional Papers.

Published by the World Agroforestry Centre

Southeast Asia Regional Programme

Jl. CIFOR, Situ Gede, Sindang Barang

Bogor, West Java

INDONESIA

Tel: +62 2518625415

Fax:+62 2518625416

Email: icraf@cgiar.org

Internet: www.worldagroforestry.org

Winrock International

2101 Riverfront Drive

Little Rock, Arkansas 72202

Phone: 1.501.280.3000

Fax: 1.501.280.3090

Email: information@winrock.org

Internet: http:/www.winrock.org/

(C) World Agroforestry Centre 2011

Working Paper nr 136 


\section{About The Authors}

Khalilal Mitras completed a Bachelor of Science degree at the Department of Agronomy, Faculty of Agriculture, Syiah Kuala University. This working paper was part of his research study.

James M. Roshetko is a Senior Integrated Natural Resource Management Scientist with The World Agroforestry Centre (ICRAF) and Winrock International. He is currently the Leader of ICRAF's Southeast Asia Trees and Market Unit with 30 years of experience, including 23 years in South and Southeast Asia. His research and development interests are improving smallholder tree-based systems to achieve local livelihood objectives and public environmental goals.

Prof. Dr. Ir. Sabaruddin is a professor in the Faculty of Agriculture, Syiah Kuala University.

Nurhayati is a lecturer in the Faculty of Agriculture, Syiah Kuala University. 


\begin{abstract}
The growth of three rambutan varieties (Nephelium lappaceum L.) was evaluated on three different nursery media at the agricultural experimental station of Syiah Kuala University, Darussalam Banda Aceh. The seed of rambutan varieties glu, nona and binjai were collected from a community plantation in Padang Tiji district. The nursery medium tested included a farmer-made compost and two researcher-made composts. The experimental design used was a factorial Randomize Complete Block Design (RCBD) 3 varieties x 3 nursery media, replicated three times. The growth parameters measured were seedling height $(\mathrm{cm})$, stem diameter $(\mathrm{mm})$, leaf area $\left(\mathrm{cm}^{2}\right)$, fresh weight of seedlings $(\mathrm{g})$, dried weight of seedlings (g), root length $(\mathrm{cm})$, root number, and root weight $(\mathrm{g})$. Measurements were made at 30, 45, 60 and 75 days after planting. Analysis of variance and honestly significant difference tests were used to analyze the growth data. Results show that variety glu had greater diameter growth and dry weight than other varieties; supporting local beliefs and practice that variety glu is a better rootstock. Additionally, the farmer compost promoted significantly better root growth compared to the other composts.
\end{abstract}

\title{
Keywords
}

vegetative propagation, farmer propagation practices, rootstock quality, post-disaster and post-conflict land rehabilitation 


\section{Acknowledgements}

The work described in this document was funded by the Canadian International Development Agency (CIDA) through the Rehabilitation of Agricultural Systems in Aceh - Developing Nurseries of Excellence (NOEL). (Arrangement: 7045366) 


\section{Contents}

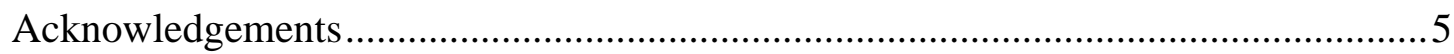

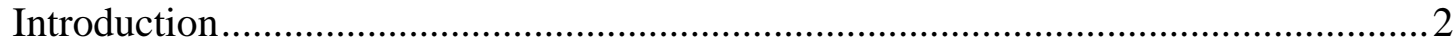

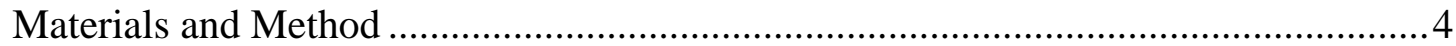

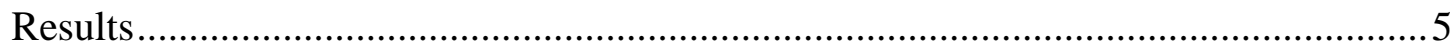

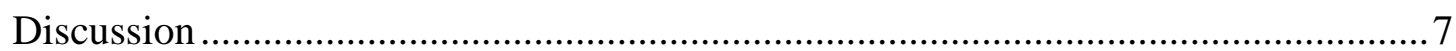

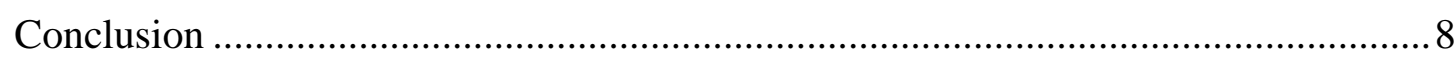

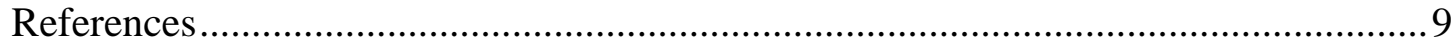




\section{Introduction}

Rambutan (Nephelium lappaceum L.) is a large fruit tree of the Sapindacaea family attaining heights of $20 \mathrm{~m}$; clonal trees are smaller (4-7 m). It thrives in the humid lowlands to $600 \mathrm{~m}$ with minimum annual rainfall of $2500 \mathrm{~mm}$. The species' range includes the Southeast Asian archipelago and mainland. It is extensively cultivated across humid tropical Asia and in small quantities in humid tropical Australia, Africa, and America (van Welzen and Verheij, 1992), including Hawaii. The fruit is round to oval, 5x7 $\mathrm{cm}$, and covered with supple spines. This last feature gives raise to the species' common name; as the Indonesian word rambut means hair. Rambutan is sometimes called hairy fruit or hairy lychee.

The tree is primarily cultivated for its fruit, which is sweet, juicy and eaten fresh. All other uses are minor. A $100 \mathrm{~g}$ serving of the fruit contains: $0.9 \mathrm{~g}$ protein, $0.1 \mathrm{~g}$ fat, $14.5 \mathrm{~g}$ carbohydrates, $1.1 \mathrm{~g}$ fibre, 4 IU (international units) Vitamin A, 31 mg vitamin C, 264 kJ energy, and 82.9 g water (van Welzen and Verheij, 1992). There is a strong local, domestic and export demand for rambutan fruit. Indonesia produced 705,823 tons of rambutan in 2007 (BPS, 2007).

Rambutan is a priority species in Indonesia, Malaysia, Thailand, the Philippines and Vietnam (Yaacob and Subhadrabandhu, 1995; Rasip et al 1999; Gunasena and Roshetko 2000). In Indonesia it is a common component of smallholder agroforestry systems in Sumatra, Java, West Kalimantan, and Sulawesi; and a secondary component of agroforestry systems in the humid parts of Nusa Tenggara (Lombok and Flores) (Penot, 1999; Roshetko et al., 2002a; Manurung et al., 2005; Otsama and Sumantri, 1999; van Welzen and Verheij, 1992; Roshetko et al. 2002b). Household consumption is an important contribution to rural nutrition in Indonesia (Mahisworo et al, 2000).

In Aceh, although cultivation is traditional and non-intensive, rambutan is an important commercial and smallholder crop. Production in 2007 was 38,847 tons (BPS, 2007). The 2004 Christmas tsunami devastated much of Aceh, killing 200,000 people and destroying much of the agricultural production land, include smallholder tree crops, along the west coast (FAO 2005). The tsunami also played an important role in ending the 30-year civil conflict (Waizeneggar, 2007). In the post-tsunmai and postconflict period, once rescue and relief work ended, there was a strong effort to rehabilitate the landuse systems that are the foundation of the rural economy. This effort required a large number of quality tree seedlings. Rambutan was one of the priority species for land rehabilitation (Green, 2007; Roshetko et al., in press). Aceh does not have a strong tradition of local seedling production. Most land rehabilitation activities in Aceh are supported with seedlings sourced in Medan (Martini et al, in press).

The Nurseries of Excellence (NOEL) Program was implemented by the World Agroforestry Centre (ICRAF) and Winrock International, through the support of the Canadian International Development 
Agency (CIDA) to enhance post-tsunami rehabilitation by improving agroforestry-based livelihoods with productive tree crops produced in community-based tree nurseries. Specifically, NOEL empowered smallholder men and women farmers to gain access to high quality planting materials and provide them with the skills necessary to establish and operate tree nurseries and tree gardens. The program supported research by university students, including a study to evaluate the response of three common rambutan varieties to indigenous nursery media and alternatives made by researchers. The objectives were to determine which nursery media facilitated the production of healthy seedlings and identify any variety effects. Results of the research are reported in this paper. 


\section{Materials and Method}

Site. The study was conducted at the experimental station of the Agriculture Faculty, Syiah Kuala University, Darussalam Banda Aceh from January to April 2008. The station is at 2 masl, temperatures range from 28 to $33^{\circ} \mathrm{C}$, annual rainfall from 1500 to $2000 \mathrm{~mm}$.

Varieties. The rambutan varieties included in the study were glu (V1 - syn. glue); nona (V2 - syn. mona), and binjai (V3 - syn. brahrang and belarang). Binjai is the preferred variety in Aceh and popular throughout Indonesia. Nona is also a popular variety. Both binjai and nona are registered commercial varieties by BPSB (Balai Pengawasan dan Sertifikasi Benih) (Martini et al. 2011). Glu is a sour variety consumed and sold locally. It is considered a good rootstock for grafting operations (preferred over binjai) and commonly used as such due to its abundance (Nazar Indris, personal communication ${ }^{1}$ ). The seeds of all three varieties were collected from a community plantation in Padang Tiji district.

Nursery Media. The nursery media for this study was made by mixing compost with top soil at a ratio of 1:2 compost to soil. The top soil used was collected from the upper 20-cm of a research plot at the university experimental station. The three composts were two composts (M1 and M2) made by researchers and an indigenous compost (M3) made by farmers in Kueh village. Compositions of the composts were:

M1: $10 \mathrm{~kg}$ of Leucanea leucocephala foliage, $50 \mathrm{~kg}$ of manure, $45 \mathrm{~kg}$ of bran, $1 \mathrm{~kg}$ red sugar, $500 \mathrm{ml}$ of EM-4 solution.

M2: $10 \mathrm{~kg}$ of grass foliage, $50 \mathrm{~kg}$ of manure, $45 \mathrm{~kg}$ of bran, $1 \mathrm{~kg}$ red sugar, $500 \mathrm{ml}$ of EM-4 solution.

M3: $50 \mathrm{~kg}$ grass and leaves, $50 \mathrm{~kg}$ of manure, $1 \mathrm{~kg}$ red sugar, $300 \mathrm{ml}$ of EM-4 solution

The EM-4 solution was applied to enhance the composting process. All three composts fermented for a minimum of 30 days.

Seedling Production. The seeds were sown into germination boxes with the radiacle down and plumule up. Twenty-two days after sowing germinants were transplanted into polybags containing the nursery media indicated above, one germinant per bag. The polybags used in this study were $30 \mathrm{x} 25$ $\mathrm{cm}$. Following transplanting, polybags were arranged according to the experimental design.

Experimental Design and Analysis. The experimental design was a factorial Randomized Complete Block Design (RBD) of 3 varieties x 3 soil media, a total of 9 treatments. Each treatment was replicated 3 times, for a total of 27 experimental units. Each unit consisted of 3 plants, for a total of 81 plants in the study.

\footnotetext{
${ }^{1}$ Nazar Idris, former Head of District Estate Crops and Forestry Office, Pidie.
} 
Seedling growth data was collected on the following variables: seedling height $(\mathrm{cm})$, stem diameter $(\mathrm{mm})$, leaf area $\left(\mathrm{cm}^{2}\right)$, fresh weight of seedlings ( $\left.\mathrm{g}\right)$, dried weight of seedlings ( $\left.\mathrm{g}\right)$, root length $(\mathrm{cm})$, root number, and root weight (g). Height and stem diameter data was collected at 30, 45, 60 and 75 days after planting (DAP). All other data was collected only at 75 DAP. Analysis of variance (ANOVA) and honestly significant difference (HSD) tests were used to analyze the data.

\section{Results}

Varieties. Results show significant differences in stem diameter growth and seedling dried weight between varieties (Table 1). At the age of 30, 45, and 60 DAP variety glu and binjai had significantly larger stem diameter (10-13\%) than variety nona. At 75 DAP only variety glu had a significantly lager stem diameter (12\%) than variety nona; there was no significant difference in stem diameter between varieties glu and binjai. At 75 DAP variety glu had a significantly greater seedling dried weight (38\%) compared to variety binjai. There was no significant difference in the other growth parameters between varieties.

Table 1. Growth parameters of three rambutan varieties at 30, 45, 60 and 75 days after planting (DAP).

\begin{tabular}{|c|c|c|c|c|c|}
\hline \multirow{2}{*}{ Changer } & \multirow{2}{*}{ Aceh Rambutan Variety } & \multicolumn{4}{|c|}{ Seedling Age } \\
\hline & & 30 DAP & 45 DAP & 60 DAP & 75 DAP \\
\hline \multirow{4}{*}{$\begin{array}{l}\text { Stem Diameter } \\
(\mathrm{mm})\end{array}$} & R1 - Rambutan Glu & $2.54 \mathrm{~b}$ & $2.71 \mathrm{~b}$ & $2.90 \mathrm{ab}$ & 3.19ab \\
\hline & R2 - Rambutan Nona & $2.30 \mathrm{c}$ & $2.45 \mathrm{c}$ & $2.57 \mathrm{c}$ & $2.84 \mathrm{c}$ \\
\hline & R3 - Rambutan Binjai & $2.58 \mathrm{ab}$ & $2.77 a b$ & $2.88 \mathrm{~b}$ & $3.08 \mathrm{bc}$ \\
\hline & $H S D_{0.05}$ & 0.21 & 0.22 & 0.24 & 0.30 \\
\hline \multirow{3}{*}{$\begin{array}{l}\text { Seedling Height } \\
\text { (cm) }\end{array}$} & R1 - Rambutan Glu & 20.00 & 22.69 & 24.19 & 26.09 \\
\hline & R2 - Rambutan Nona & 20.28 & 22.94 & 24.81 & 27.61 \\
\hline & R3 - Rambutan Binjai & 19.35 & 21.81 & 23.69 & 26.51 \\
\hline \multirow{3}{*}{ Leaf Area $\left(\mathrm{cm}^{2}\right)$} & R1 - Rambutan Glu & & & & 18.28 \\
\hline & R2 - Rambutan Nona & & & & 17.35 \\
\hline & R3 - Rambutan Binjai & & & & 14.71 \\
\hline \multirow{3}{*}{ Root Length (cm) } & R1 - Rambutan Glu & & & & 14.71 \\
\hline & R2 - Rambutan Nona & & & & 14.80 \\
\hline & R3 - Rambutan Binjai & & & & 14.55 \\
\hline \multirow{3}{*}{$\begin{array}{l}\text { Fresh Weight of } \\
\text { Seedling }(\mathrm{g})\end{array}$} & R1 - Rambutan Glu & & & & 4.10 \\
\hline & R2 - Rambutan Nona & & & & 3.51 \\
\hline & R3 - Rambutan Binjai & & & & 3.48 \\
\hline \multirow{4}{*}{$\begin{array}{l}\text { Dried Weight } \\
\text { Seedling (g) }\end{array}$} & R1 - Rambutan Glu & & & & $1.35 \mathrm{a}$ \\
\hline & R2 - Rambutan Nona & & & & $1.07 \mathrm{ab}$ \\
\hline & R3 - Rambutan Binjai & & & & $0.98 \mathrm{~b}$ \\
\hline & $H S D_{0,05}$ & & & & 0.33 \\
\hline \multirow{3}{*}{ Root Number } & R1 - Rambutan Glu & & & & 21.30 \\
\hline & R2 - Rambutan Nona & & & & 15.30 \\
\hline & R3 - Rambutan Binjai & & & & 14.11 \\
\hline
\end{tabular}




\begin{tabular}{lll}
\hline \multirow{3}{*}{ Root Weight (g) } & R1 - Rambutan Glu & 0.37 \\
\cline { 2 - 3 } & R2 - Rambutan Nona & 0.35 \\
\cline { 2 - 3 } & R3 - Rambutan Binjai & 0.40 \\
\hline
\end{tabular}

Note: The numbers followed by the same letter in the same column is not significantly different in $5 \%$ probability $\left(\mathrm{HSD}_{0.05}\right)$.

Nursery Media. Results indicate nursery media had a significant effect on root length at 75 DAP (Table 2). Seedlings grown in farmer compost demonstrated 54\% and 18\% greater root length compared to seedlings grown in the other nursery media. Nursery media did not have significant effect on stem diameter, stem height, leaf area, seedling fresh weight, seedling dry weight, root number or root weight. Analysis demonstrated that there was no interaction between nursery media and rambutan variety, meaning that the difference in seedling responses to nursery media was not affected by rambutan variety and vice versa.

Table 2. Effect of Nursery Media on Rambutan Seedling Growth at 30, 45, 60 and 75 days after planting (DAP).

\begin{tabular}{|c|c|c|c|c|c|}
\hline \multirow{2}{*}{ Changer } & \multirow{2}{*}{ Nursery Media } & \multicolumn{4}{|c|}{ Seedling Age } \\
\hline & & 30 DAP & 45 DAP & 60 DAP & 75 DAP \\
\hline \multirow{3}{*}{$\begin{array}{l}\text { Stem Diameter } \\
(\mathrm{mm})\end{array}$} & M1 - Leucaena media & 2.41 & 2.56 & 2.69 & 2.87 \\
\hline & M2 - Grass media & 2.51 & 2.69 & 2.83 & 3.15 \\
\hline & M3 - Farmer compost & 2.50 & 2.68 & 2.83 & 3.09 \\
\hline \multirow{3}{*}{$\begin{array}{l}\text { Seedling Height } \\
(\mathrm{cm})\end{array}$} & M1 - Leucaena media & 20.04 & 21.61 & 23.56 & 26.09 \\
\hline & M2 - Grass media & 19.59 & 23.44 & 25.38 & 27.67 \\
\hline & M3 - Farmer compost & 20.00 & 22.39 & 23.75 & 25.94 \\
\hline \multirow{3}{*}{ Leaf Area $\left(\mathrm{cm}^{2}\right)$} & M1 - Leucaena media & & & & 15.82 \\
\hline & M2 - Grass media & & & & 18.40 \\
\hline & M3 - Farmer compost & & & & 16.12 \\
\hline \multirow{4}{*}{ Root Length (cm) } & M1 - Leucaena media & & & & $14.93 \mathrm{~b}$ \\
\hline & M2 - Grass media & & & & $11.46 \mathrm{c}$ \\
\hline & M3 - Farmer compost & & & & $17.62 \mathrm{a}$ \\
\hline & $H S D_{0,05}$ & & & & 2.57 \\
\hline \multirow{3}{*}{$\begin{array}{l}\text { Fresh Weight of } \\
\text { Seedling (g) }\end{array}$} & M1 - Leucaena media & & & & 3.37 \\
\hline & M2 - Grass media & & & & 3.62 \\
\hline & M3 - Farmer compost & & & & 4.10 \\
\hline \multirow{3}{*}{$\begin{array}{l}\text { Dried Weight } \\
\text { Seedling (g) }\end{array}$} & M1 - Leucaena media & & & & 0.98 \\
\hline & M2 - Grass media & & & & 1.18 \\
\hline & M3 - Farmer compost & & & & 1.24 \\
\hline \multirow{3}{*}{ Root Number } & M1 - Leucaena media & & & & 18.00 \\
\hline & M2 - Grass media & & & & 15.41 \\
\hline & M3 - Farmer compost & & & & 17.30 \\
\hline
\end{tabular}




\begin{tabular}{lll}
\hline \multirow{3}{*}{ Root Weight (g) } & M1 - Leucaena media & 0.36 \\
\cline { 2 - 3 } & M2 - Grass media & 0.36 \\
\cline { 2 - 3 } & M3 - Farmer compost & 0.39 \\
\hline
\end{tabular}

Note: The numbers followed by the same letter in the same column is not significantly different in $5 \%$ probability $\left(\mathrm{HSD}_{0.05}\right)$.

\section{Discussion}

Rambutan is a priority species in Aceh for post-tsunami, post-conflict land and livelihood rehabilitation (Green, 2007; Roshetko et al., in press). The success of rehabilitation activities requires the production of quality seedlings in sufficient quantities to meet demand. Demand by government agencies exceeded 5,000,000 seedlings in 2008 (Martini, et al in press). The production of quality rambutan seedlings is usually by vegetative propagation (Purnomosidhi et al., 2007). Rootstocks should be healthy with a basal diameter of 5-7 (about the diameter of a pencil), approximately 4-5 months old. Varieties with healthy root systems (greater root density and root number) make better rootstocks (Mahisworo et al., 2000). In this study, the rambutan variety glu demonstrated significantly better stem diameter growth compared to variety nona and greater seedling dry weight compared to variety binjai. The glu variety also showed a trend to have greater number of roots, seedling fresh weight, and leaf area - but those differences were not significant. While results are not conclusive, the performance of variety glu in this study supports local beliefs and practices that it is a better rootstock.

A good nursery media should have good physical, chemical, and biological properties that provide sufficient nutrients, texture, porosity, and moisture to produce healthy seedlings (Hakim et al., 1986). One method to ensure the quality of nursery media is to mix soil with compost, manure, or other organic matters (Suterdjo and Kartasapoetra, 1990). In Aceh during the post-tsunami, post-conflict period effective microorganism (EM) technology was widely promoted as an appropriate means to facilitate nursery production and land rehabilitation. The EM concept maintains that incorporating beneficial positive microorganisms to soil/plant ecosystems can improve soil quality, soil health, as well as growth, yield, and quality of crops. EM technology is not promoted as a substitute to good management practices, but rather a compliment to optimize their beneficial effects, improving agriculture production (Higa and Parr, 1994). In this study, rambutan seedlings grown in traditional farmer compost media had significantly longer roots (54\% and 18\%) compared to other composts. Seedlings grown in the farmer compost also had better seedling weight, root number, and root weight characteristics - but those differences were not significant. The traditional farmer compost appears to be a better nursery media than the two alternatives. 


\section{Conclusion}

Results support local beliefs and practices that rambutan variety glu is a superior rootstock. In this study, seedlings of variety glu demonstrated better diameter growth and dry weight than varieties nona and binjai. The glu variety also showed a trend to have greater leaf area, seedling fresh weight, and number of roots. The study also indicates that the farmer compost promoted significantly better root growth compared to the other composts. In retrospect it would have been better to continue the study for 120 days, which would have yielded seedlings of approximately 5-7 mm diameter, the minimum size for vegetative propagation. Additionally, including a large number of seedlings (experimental units) in the study would have increased the degrees of freedom and improved the precision of the statistical analysis. 


\section{References}

BPS. 2007. Statistic of Annual Fruit and Vegetable Production. Biro Pusat Statistik. Jakarta. http://www.hortikultura.go.id/index.php?option=com_wrapper\&Itemid=226

FAO. 2005. FAO/WFP Food Supply and Demand Assessment for Aceh Province and Nias Island (Indonesia). World Food Programme, Special Report. FAO. www.fao.org/docrep/012/ak334e/ak334e00.HTM

Green A. 2007. Fruit Tree Crops and Nurseries in Aceh: A Rapid Market Appraisal of Aceh Jaya and Aceh Barat. Bogor, Indonesia: Winrock International and World Agroforestry Centre (ICRAF) Southeast Asia Program. 31 p.

Gunasena, H.P.M. and J.M. Roshetko. 2000. Tree Domestication in Southeast Asia: Results of a Regional Study on Institutional Capacity, International Centre for Research in Agroforestry (ICRAF) Bogor, Indonesia.

Hakim N.M.Y Nyakpa, A.M Lubis, S.G. Nugroho, M R. Saul. M.A. Diah, Go Ban Hong, and H.H Bailey. 1986. The Basic of Soil Science, Lampung University Press. Bandar Lampung, Indonesia. $488 \mathrm{p}$.

Higa, T and J.F. Parr. 1994. Beneficial and Effective Microorganisms for a Sustainable Agriculture and Environment. International Nature Farming Research Center. Atami, Japan. 20 p. http://www.agriton.nl/higa.html

Mahisworo Kusno, R. Susanto, and A. Agustinus Anung. 2000 Bertanam rambutan, Penebar Swadaya, Jakarta page 88.

Manurung, G.E.S., J.M. Roshetko, S. Budidarsono, and J.C. Tukan. 2005. Dudukuhan Traditional Tree Farming Systems for Poverty Reduction. In: Jan vander Ploeg and Andres B. Masipiquena (eds), The future of the Sierra Madre: responding to social and ecological changes. Proceedings of the fifth international conference on environment and development. Cagayan Valley Program on Environment and Development (CVPED). Golden Press, Tuguegarao, Philippines.

Martini, E., J.M. Roshetko, P. Purnomosidhi, J. Tarigan, N. Idris, and T. Zulfadhli. In press. Sumber-Sumber dan Permintaan untuk Plasma Nutfah Buah-Buahan Dari Petani Skala Kecil Setelah Tsunami dan Konflik di Provinsi Nanggroe Aceh Darussalam, Indonesia.

Otsama, A. and I.G.K. Sumantri, 1999. Finding alternative agroforestry tree species in connection with timber estate development in grassland and bushland in West Kalimantan, Indonesia. In: J.M. Roshetko and D.O. Evans. (eds) Domestication of agroforestry trees in Southeast Asia. Forest, Farm, and Community Tree Research Reports, special issue 1999. pp. 85-93. Taiwan Forestry Research Institute and Council of Agriculture, Taiwan, Republic of China; Winrock 
International, Morrilton, Arkansas, USA; and International Centre for Research in Agroforestry, Nairobi, Kenya.

Penot, E. 1999 Trees associated with rubber in rubber agroforestry systems.In: J.M. Roshetko and D.O. Evans. (eds) Domestication of agroforestry trees in Southeast Asia. Forest, Farm, and Community Tree Research Reports, special issue 1999. pp. 94 -109. Taiwan Forestry Research Institute and Council of Agriculture, Taiwan, Republic of China; Winrock International, Morrilton, Arkansas, USA; and International Centre for Research in Agroforestry, Nairobi, Kenya.

Purnomosidhi P, Suparman, Roshetko JM and Mulawarman . 2007. Perbanyakan dan budidaya tanaman buah-buahan: Pedoman Lapang edisi kedua. Bogor, Indonesia. World Agroforestry Centre-ICRAF, SEA Regional Office and Winrock International. 51 p.

Rasip, A.G.Ab., M. Moh. Noor, A.Y. Zuhaidi, and A.W. Mahmud. 1999. Tree domestication and agroforestry in Malaysia. In: J.M. Roshetko and D.O. Evans. (eds) Domestication of agroforestry trees in Southeast Asia. Forest, Farm, and Community Tree Research Reports, special issue 1999, pp 39-44. Taiwan Forestry Research Institute and Council of Agriculture, Taiwan, Republic of China; Winrock International, Morrilton, Arkansas, USA; and International Centre for Research in Agroforestry, Nairobi, Kenya.

Roshetko, J.M., M. Delaney, K. Hairiah, and P. Purnomosidhi. 2002a. Carbon stocks in Indonesian homegarden systems: Can smallholder systems be targeted for increased carbon storage? American Journal of Alternative Agriculture 17 (2):138-148.

Roshetko, J.M., Mulawarman, W.J. Santoso and I.N. Oka. 2002b. Wanatani di Nusa Tenggara. Prosiding Lokakarya Wanatani Se-Nusa Tengara, 11-14 November 2001. Denpasar, Bali. International Centre for Research in Agroforestry (ICRAF and Winrock International. Bogor, Indonesia. $164 \mathrm{p}$.

Roshetko, J.M., P. Purnomosidhi, N. Idris, and J. Tarigan. In press. Rehabilitating agricultural systems with tree nurseries: lessons from the Aceh Nurseries of Excellence Program (NOEL).

Sutedjo, M.M and A.G. Kartosapoetro. 1990. Fertilizer and Fertilizing Methods. Mina Aksara Press. Jakarta, Indonesia. 177 p.

van Wekzen, P.C. and E.W.M. Verheij. 1992. Nephelium lappaceum L. In: E.W.M. Verheij and R.E. Coronel (eds), Plant Resources of South-East Asia, No. 2 Edible Fruits and Nuts. PROSEA Foundation, Bogor, Indonesia and Pudoc-DLO, Wageningen, the Netherlands. Waizenegger, Arno. 2007. Armed Separatism and the 2004 Tsunami in Aceh. Canada Asia Commentary.

Yaacob, O and S. Subhadrabandhu. 1995. The Production of Economic Fruits in Southeast Asia. Oxford University Press. Kuala Lumpur, Malaysia. 419 p. 


\section{WORKING PAPERS IN THIS SERIES}

1. Agroforestry in the drylands of eastern Africa: a call to action

2. Biodiversity conservation through agroforestry: managing tree species diversity within a network of community-based, nongovernmental, governmental and research organizations in western Kenya.

3. Invasion of prosopis juliflora and local livelihoods: Case study from the Lake Baringo area of Kenya

4. Leadership for change in farmers organizations: Training report: Ridar Hotel, Kampala, 29th March to 2nd April 2005.

5. Domestication des espèces agroforestières au Sahel : situation actuelle et perspectives

6. Relevé des données de biodiversité ligneuse: Manuel du projet biodiversité des parcs agroforestiers au Sahel

7. Improved land management in the Lake Victoria Basin: TransVic Project's draft report.

8. Livelihood capital, strategies and outcomes in the Taita hills of Kenya

9. Les espèces ligneuses et leurs usages: Les préférences des paysans dans le Cercle de Ségou, au Mali

10. La biodiversité des espèces ligneuses: Diversité arborée et unités de gestion du terroir dans le Cercle de Ségou, au Mali

11. Bird diversity and land use on the slopes of Mt. Kilimanjaro and the adjacent plains, Tanzania

12. Water, women and local social organization in the Western Kenya Highlands

13. Highlights of ongoing research of the World Agroforestry Centre in Indonesia

14. Prospects of adoption of tree-based systems in a rural landscape and its likely impacts on carbon stocks and farmers' welfare: The FALLOW Model Application in Muara Sungkai, Lampung, Sumatra, in a 'Clean Development Mechanism' context

15. Equipping integrated natural resource managers for healthy Agroforestry landscapes.

17. Agro-biodiversity and CGIAR tree and forest science: approaches and examples from Sumatra.

18. Improving land management in eastern and southern Africa: A review of policies.

19. Farm and household economic study of Kecamatan Nanggung, Kabupaten Bogor, Indonesia: A socio-economic base line study of Agroforestry innovations and livelihood enhancement.

20. Lessons from eastern Africa's unsustainable charcoal business.

21. Evolution of RELMA's approaches to land management: Lessons from two decades of research and development in eastern and southern Africa

22. Participatory watershed management: Lessons from RELMA's work with farmers in eastern Africa.

23. Strengthening farmers' organizations: The experience of RELMA and ULAMP.

24. Promoting rainwater harvesting in eastern and southern Africa.

25. The role of livestock in integrated land management. 
26. Status of carbon sequestration projects in Africa: Potential benefits and challenges to scaling up.

27. Social and Environmental Trade-Offs in Tree Species Selection: A Methodology for Identifying Niche Incompatibilities in Agroforestry [Appears as AHI Working Paper no. 9]

28. Managing tradeoffs in agroforestry: From conflict to collaboration in natural resource management. [Appears as AHI Working Paper no. 10]

29. Essai d'analyse de la prise en compte des systemes agroforestiers pa les legislations forestieres au Sahel: Cas du Burkina Faso, du Mali, du Niger et du Senegal.

30. Etat de la recherche agroforestière au Rwanda etude bibliographique, période 1987-2003

31. Science and technological innovations for improving soil fertility and management in Africa: A report for NEPAD's Science and Technology Forum.

32. Compensation and rewards for environmental services.

33. Latin American regional workshop report compensation.

34. Asia regional workshop on compensation ecosystem services.

35. Report of African regional workshop on compensation ecosystem services.

36. Exploring the inter-linkages among and between compensation and rewards for ecosystem services CRES and human well-being

37. Criteria and indicators for environmental service compensation and reward mechanisms: realistic, voluntary, conditional and pro-poor

38. The conditions for effective mechanisms of compensation and rewards for environmental services.

39. Organization and governance for fostering Pro-Poor Compensation for Environmental Services.

40. How important are different types of compensation and reward mechanisms shaping poverty and ecosystem services across Africa, Asia \& Latin America over the Next two decades?

41. Risk mitigation in contract farming: The case of poultry, cotton, woodfuel and cereals in East Africa.

42. The RELMA savings and credit experiences: Sowing the seed of sustainability

43. Yatich J., Policy and institutional context for NRM in Kenya: Challenges and opportunities for Landcare.

44. Nina-Nina Adoung Nasional di So! Field test of rapid land tenure assessment (RATA) in the Batang Toru Watershed, North Sumatera.

45. Is Hutan Tanaman Rakyat a new paradigm in community based tree planting in Indonesia?

46. Socio-Economic aspects of brackish water aquaculture (Tambak) production in Nanggroe Aceh Darrusalam.

47. Farmer livelihoods in the humid forest and moist savannah zones of Cameroon.

48. Domestication, genre et vulnérabilité : Participation des femmes, des Jeunes et des catégories les plus pauvres à la domestication des arbres agroforestiers au Cameroun.

49. Land tenure and management in the districts around Mt Elgon: An assessment presented to the Mt Elgon ecosystem conservation programme.

50. The production and marketing of leaf meal from fodder shrubs in Tanga, Tanzania: A propoor enterprise for improving livestock productivity.

51. Buyers Perspective on Environmental Services (ES) and Commoditization as an approach to liberate ES markets in the Philippines. 
52. Towards Towards community-driven conservation in southwest China: Reconciling state and local perceptions.

53. Biofuels in China: An Analysis of the Opportunities and Challenges of Jatropha curcas in Southwest China.

54. Jatropha curcas biodiesel production in Kenya: Economics and potential value chain development for smallholder farmers

55. Livelihoods and Forest Resources in Aceh and Nias for a Sustainable Forest Resource Management and Economic Progress

56. Agroforestry on the interface of Orangutan Conservation and Sustainable Livelihoods in Batang Toru, North Sumatra.

57. Assessing Hydrological Situation of Kapuas Hulu Basin, Kapuas Hulu Regency, West Kalimantan.

58. Assessing the Hydrological Situation of Talau Watershed, Belu Regency, East Nusa Tenggara.

59. Kajian Kondisi Hidrologis DAS Talau, Kabupaten Belu, Nusa Tenggara Timur.

60. Kajian Kondisi Hidrologis DAS Kapuas Hulu, Kabupaten Kapuas Hulu, Kalimantan Barat.

61. Lessons learned from community capacity building activities to support agroforest as sustainable economic alternatives in Batang Toru orang utan habitat conservation program (Martini, Endri et al.)

62. Mainstreaming Climate Change in the Philippines.

63. A Conjoint Analysis of Farmer Preferences for Community Forestry Contracts in the Sumber Jaya Watershed, Indonesia.

64. The highlands: a shared water tower in a changing climate and changing Asia

65. Eco-Certification: Can It Deliver Conservation and Development in the Tropics.

66. Designing ecological and biodiversity sampling strategies. Towards mainstreaming climate change in grassland management.

67. Towards mainstreaming climate change in grassland management policies and practices on the Tibetan Plateau

68. An Assessment of the Potential for Carbon Finance in Rangelands

69 ECA Trade-offs Among Ecosystem Services in the Lake Victoria Basin.

69. The last remnants of mega biodiversity in West Java and Banten: an in-depth exploration of RaTA (Rapid Land Tenure Assessment) in Mount Halimun-Salak National Park Indonesia

70. Le business plan d'une petite entreprise rurale de production et de commercialisation des plants des arbres locaux. Cas de quatre pépinières rurales au Cameroun.

71. Les unités de transformation des produits forestiers non ligneux alimentaires au Cameroun. Diagnostic technique et stratégie de développement Honoré Tabuna et Ingratia Kayitavu.

72. Les exportateurs camerounais de safou (Dacryodes edulis) sur le marché sous régional et international. Profil, fonctionnement et stratégies de développement.

73. Impact of the Southeast Asian Network for Agroforestry Education (SEANAFE) on agroforestry education capacity.

74. Setting landscape conservation targets and promoting them through compatible land use in the Philippines.

75. Review of methods for researching multistrata systems.

76. Study on economical viability of Jatropha curcas L. plantations in Northern Tanzania assessing farmers' prospects via cost-benefit analysis

77. Cooperation in Agroforestry between Ministry of Forestry of Indonesia and International Center for Research in Agroforestry 
78. "China's bioenergy future. an analysis through the Lens if Yunnan Province

79. Land tenure and agricultural productivity in Africa: A comparative analysis of the economics literature and recent policy strategies and reforms

80. Boundary organizations, objects and agents: linking knowledge with action in Agroforestry watersheds

81. Reducing emissions from deforestation and forest degradation (REDD) in Indonesia: options and challenges for fair and efficient payment distribution mechanisms

82. Mainstreaming climate change into agricultural education: challenges and perspectives

83. Challenging conventional mindsets and disconnects in conservation: the emerging role of eco-agriculture in Kenya's landscape mosaics

84. Lesson learned RATA garut dan bengkunat: suatu upaya membedah kebijakan pelepasan kawasan hutan dan redistribusi tanah bekas kawasan hutan

85. The emergence of forest land redistribution in Indonesia

86. Commercial opportunities for fruit in Malawi

87. Status of fruit production processing and marketing in Malawi

88. Fraud in tree science

89. Trees on farm: analysis of global extent and geographical patterns of agroforestry

90. The springs of Nyando: water, social organization and livelihoods in Western Kenya

91. Building capacity toward region-wide curriculum and teaching materials development in agroforestry education in Southeast Asia

92. Overview of biomass energy technology in rural Yunnan (Chinese - English abstract)

93. A pro-growth pathway for reducing net GHG emissions in China

94. Analysis of local livelihoods from past to present in the central Kalimantan Ex-Mega Rice Project area

95. Constraints and options to enhancing production of high quality feeds in dairy production in Kenya, Uganda and Rwanda

96. Agroforestry education in the Philippines: status report from the Southeast Asian Network for Agroforestry Education (SEANAFE)

97. Economic viability of Jatropha curcas L. plantations in Northern Tanzania- assessing farmers' prospects via cost-benefit analysis.

98. Hot spot of emission and confusion: land tenure insecurity, contested policies and competing claims in the central Kalimantan Ex-Mega Rice Project area

99. Agroforestry competences and human resources needs in the Philippines

100. CES/COS/CIS paradigms for compensation and rewards to enhance environmental Services

101. Case study approach to region-wide curriculum and teaching materials development in agroforestry education in Southeast Asia

102. Stewardship agreement to reduce emissions from deforestation and degradation (REDD): Lubuk Beringin's Hutan Desa as the first village forest in Indonesia

103. Landscape dynamics over time and space from ecological perspective

104. A performance-based reward for environmental services: an action research case of "RiverCare" in Way Besai sub-watersheds, Lampung, Indonesia 
105. Smallholder voluntary carbon scheme: an experience from Nagari Paningahan, West Sumatra, Indonesia

106. Rapid Carbon Stock Appraisal (RACSA) in Kalahan, Nueva Vizcaya, Philippines

107. Tree domestication by ICRAF and partners in the Peruvian Amazon: lessons learned and future prospects in the domain of the Amazon Initiative eco-regional program

108. Memorias del Taller Nacional: "Iniciativas para Reducir la Deforestación en la region Andino - Amazónica", 09 de Abril del 2010. Proyecto REALU Peru

109. Percepciones sobre la Equidad y Eficiencia en la cadena de valor de REDD en Perú Reporte de Talleres en Ucayali, San Martín y Loreto, 2009. Proyecto REALU-Perú.

110. Reducción de emisiones de todos los Usos del Suelo. Reporte del Proyecto REALU Perú Fase 1

111. Programa Alternativas a la Tumba-y-Quema (ASB) en el Perú. Informe Resumen y Síntesis de la Fase II. 2da. versión revisada

112. Estudio de las cadenas de abastecimiento de germoplasma forestal en la amazonía Boliviana

113. Biodiesel in the Amazon

114. Estudio de mercado de semillas forestales en la amazonía Colombiana

115. Estudio de las cadenas de abastecimiento de germoplasma forestal en Ecuador

116. How can systems thinking, social capital and social network analysis help programs achieve impact at scale?

117. Energy policies, forests and local communities in the Ucayali Region, Peruvian Amazon

118. NTFPs as a Source of Livelihood Diversification for Local Communities in the Batang Toru Orangutan Conservation Program

119. Studi Biodiversitas: Apakah agroforestry mampu mengkonservasi keanekaragaman hayati di DAS Konto?

120. Estimasi Karbon Tersimpan di Lahan-lahan Pertanian di DAS Konto, Jawa Timur

121. Implementasi Kaji Cepat Hidrologi (RHA) di Hulu DAS Brantas, Jawa Timur.

122. Kaji Cepat Hidrologi di Daerah Aliran Sungai Krueng Peusangan, NAD, Sumatra

123. A Study of Rapid Hydrological Appraisal in the Krueng Peusangan Watershed, NAD, Sumatra.

124. An Assessment of farm timber value chains in Mt Kenya area, Kenya

125. A Comparative financial analysis of current land use systems and implications for the adoption of improved agroforestry in the East Usambaras, Tanzania

126. Agricultural monitoring and evaluation systems

127. Challenges and opportunities for collaborative landscape governance in the East Usambara Mountains, Tanzania

128. Transforming Knowledge to Enhance Integrated Natural Resource Management Research, Development and Advocacy in the Highlands of Eastern Africa

129. Carbon-forestry projects in the Philippines: potential and challenges The Mt Kitanglad Range forest-carbon development

130. Carbon forestry projects in the Philippines: potential and challenges. The Arakan Forest Corridor forest-carbon project

131. Carbon-forestry projects in the Philippines: potential and challenges. The Laguna Lake Development Authority's forest-carbon development project

132. Carbon-forestry projects in the Philippines: potential and challenges. The Quirino forestcarbon development project in Sierra Madre Biodiversity Corridor 
133. Carbon-forestry projects in the Philippines: potential and challenges. The Ikalahan Ancestral Domain forest-carbon development

134. The Importance of Local Traditional Institutions in the Management of Natural Resources in the Highlands of Eastern Africa

135. Socio-economic assessment of irrigation pilot projects in Rwanda 


\section{Who we are}

The World Agroforestry Centre is the international leader in the science and practice of integrating 'working trees' on small farms and in rural landscapes. We have invigorated the ancient practice of growing trees on farms, using innovative science for development to transform lives and landscapes.

\section{Our vision}

Our Vision is an 'Agroforestry Transformation' in the developing world resulting in a massive increase in the use of working trees on working landscapes by smallholder rural households that helps ensure security in food, nutrition, income, health, shelter and energy and a regenerated environment.

\section{Our mission}

Our mission is to advance the science and practice of agroforestry to help realize an 'Agroforestry Transformation' throughout the developing world.



A Future Harvest Centre supported by the CGIAR

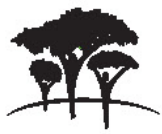

United Nations Avenue, Gigiri - PO Box 30677 - 00100 Nairobi, Kenya

Tel: +254 207224000 or vla USA +1 6508336645

Fax: +254 207224001 or via USA +1 6508336646

Southeast Asia Regional Programme - Sindang Barang, Bogor 16680

PO Box161 Bogor 16001, Indonesia

Tel: +62 2518625415 - Fax: +62 2518625416

www.worldagroforestry.org 